\title{
INTEGRATING EMPLOYEE BENEFITS AND COMPETITIVE STRATEGY
}

\author{
Margaret A. Lucero* \\ University of Wyoming \\ Laramie, WY \\ Marion M. White \\ James Madison University \\ Harrisonburg, VA
}

\begin{abstract}
As the costs of employee benefits have escalated, labor cost control to enhance product market competitiveness has become a more critical organizational concern. However, benefits which are an element of compensation have remained a relatively neglected topic in the area of strategic human resource management. This paper explores the role of employee benefits in effective strategy implementation. Three core characteristics of employee benefits practices: timing, benefit level and employee-employer relationship, are described on continuum of choices. Examples of various employee benefits practices are linked to low-cost leadership and differentiation strategies.
\end{abstract}

\section{Introduction}

As global market pressures increased during the 1980s and 1990s, labor costs have become an important concern in many organizations. As part of efforts to enhance product market competitiveness, a growing number of organizations have taken steps to control compensation costs. Accordingly, benefits have been closely scrutinized in recent years as employee benefits have increased to approximately 39 percent of total labor costs (U.S. Chamber of Commerce, 1992). As a result of cost control efforts, some organizations have eliminated benefits while others have shifted a portion of the employer's costs of benefits to the employees receiving them.

It appears, however, that these efforts to control the cost of benefits have been as unsystematic as was the growth in supplemental compensation packages. Over the years, employers added new benefits in response to factors such as government mandates, union pressures, tax incentives and employee initiatives (Milkovich \& Newman, 1993). While responding to the various stakeholder pres-

* The authors would like to thank Martin M. Greller, Robert E. Allen, Charles D. Pringle, and two anonymous reviewers for their valuable comments on this paper. 
sures to add new benefits and improve old ones, employer concern for the return received on employee benefits expenditures appear to have obtained a lower priority. Additionally, benefits are an element of the reward structure that have remained a relatively neglected topic by behavioral researchers. "At this point, benefits decisions are being primarily made based on beliefs and experience behavioral research simply does not exist to help inform such decisions" (Gerhart \& Milkovich, 1992, p. 541).

The escalating costs and the critical importance of benefits for employees provides a new impetus for linking benefits to compensation strategy, as well as to overall corporate strategy. Organizations can realize positive results by thinking strategically with respect to their employee benefits practices. For example, at GTE "benefits are those that help rightsize the work force either up or down, or motivate people to join us as a workplace of choice" (Carswell, 1993, p.12). GTE's view of benefits is indicative of the potential outcomes that can be realized by linking employee benefits to organizational strategy. At the same time, poorly conceived and executed attempts to cut the costs of benefits can interfere with the realization of important organizational goals. The purpose of this paper is to examine the contribution that employee benefits can make to an organization's ability to achieve overall strategic objectives.

An organization's reward system is one of the most powerful tools in effective strategy implementation. As a result, the reward system must be clearly and tightly linked to strategic performance. Many organizations have modified their reward systems to fit the objectives they are trying to achieve. For example, IBM changed its emphasis from sales objectives to financial objectives, and in order to make this change, has switched to pay for profits for its sales-force. Now 60 percent of commissions are tied directly to sales-force generated profits, as compared to 20 percent in the previous year (Sager, McWilliams, \& Hof, 1994). Similarly, the employee benefits portion of compensation can enhance strategy implementation when benefits and strategy are effectively linked.

\section{Integrating Employee Benefits Into Strategy Implementation}

In an area such as employee benefits, where theory-driven empirical research is sparse, the application of strategic human resource management theories can provide a valuable focus for future research and organizational decision-making. The choice of strategy has important implications for human resource management practices, because successful strategy implementation ultimately depends on the behavior of individual organizational members. Future competitive success will be increasingly reliant on a concerted managerial effort to create strategysupportive "fits" (Thompson \& Strickland, 1992). All organizational systems and goals should be supportive of the unit strategy and human resource practices are no exception.

A number of alternative theoretical frameworks are useful when linking human resource practices to strategy, and thereby providing a view of human re- 
source management activities "as being determined by proactive, strategically, intended decisions" (Wright \& McMahan, 1992, p. 300). These four strategic theories of human resource management are, the resource-based view of the firm (Barney, 1991), the behavioral perspective (Jackson, Schuler, \& Rivero, 1989; Schuler \& Jackson, 1987), cybernetic systems (Boulding, 1956) and agency/transaction cost theory (Jones, 1984). The current paper is based on the behavioral perspective, following Schuler and Jackson's (1987) model linking human resource practices with the competitive strategies described by Porter (1980). The behavioral perspective provides strong connections between employer practices and the appropriate employee role behaviors required by the implementation of the chosen competitive strategy. The Schuler and Jackson (1987) model illustrates how different employee role behaviors can be elicited through the human resource practices used by the organization, while at the same time emphasizing the need for congruence among these practices. Accordingly, the strengths of the behavioral perspective provide a beneficial foundation for examining employee role behaviors that can result from employer-sponsored employee benefits programs.

Figure 1 presents a framework for integrating employee benefits practices into corporate strategy implementation. The following discussion describes the linkages between the competitive strategies described by Porter (1980) and three core characteristics of employee benefits. Consistent with the behavioral perspective, the appropriate fit between choice of strategy and benefit practices is theorized to encourage the types of employee behaviors needed for effective strategy implementation.

\section{Figure 1}

\section{Integrating Employee Benefits into Strategy Implementation}

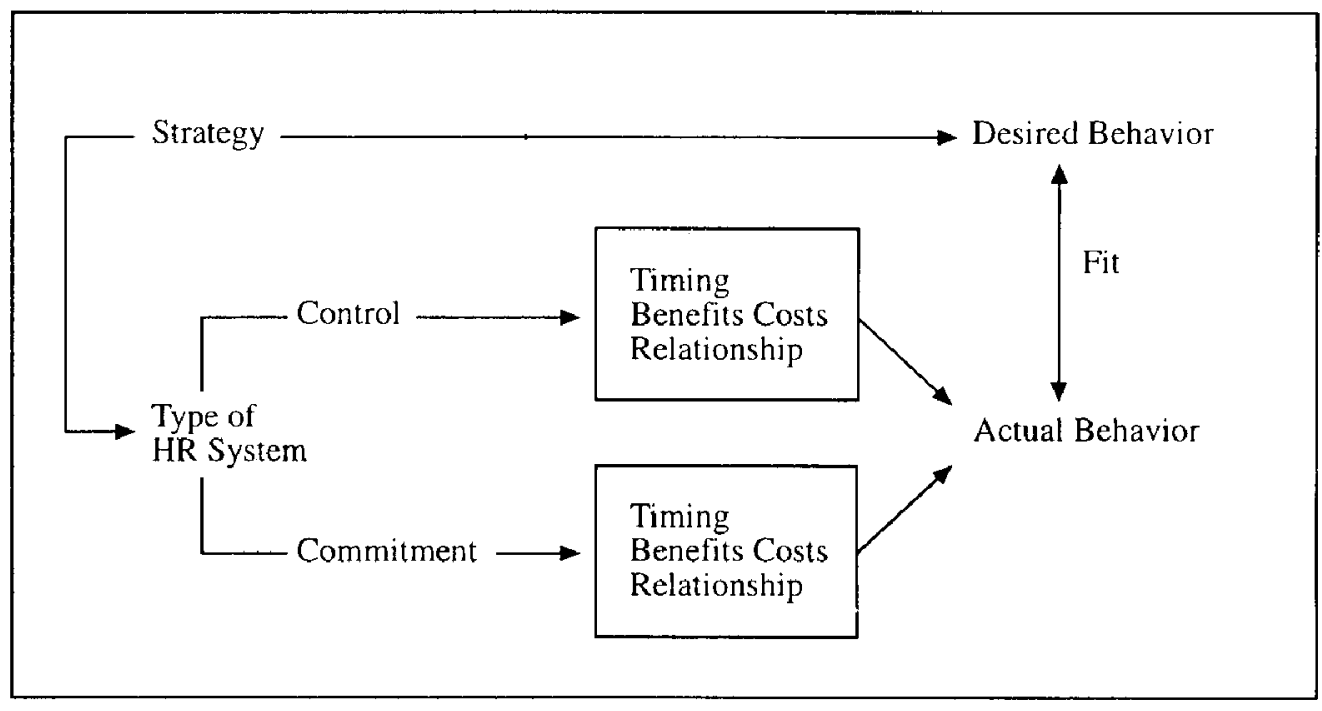


According to Porter (1985), management must select a strategy that will allow it to develop and sustain a competitive advantage in order for that organization to perform at an above-average level. Competitive strategy concerns the identification of organizational activities which provide an edge over the competition thereby allowing the organization to achieve a competitive advantage. Porter (1980) describes three approaches to competitive strategy. These are: (1) a lowcost leadership strategy, (2) a differentiation strategy, and (3) a focus or niche strategy. The characteristics of the low-cost leadership strategy include a continuous emphasis on cost reduction (while maintaining acceptable levels of quality), tight controls and attaining economies of scale. Alternatively, an organization following a differentiation strategy will seek ways to make its product or service unique. A differentiation strategy is exemplified by an emphasis on technical superiority, quality or high service. This generally requires an emphasis on quality rather than cost. An organization following a focus or niche strategy, can use either a low-cost leadership strategy or a differentiation strategy but will focus on a narrow portion of the market rather than the whole market.

Schuler and Jackson (1987) argue that successfully linking strategy and human resource practices requires an understanding of the specific role behaviors needed for successful strategy implementation. Some examples of key employee role behaviors include concern for quality, concern for quantity, risk taking, job involvement, and innovativeness. Each of these role behaviors can be conceptualized on a continuum from low to high. The specific attitudes and behaviors that will be most effective for a particular organization will depend on the type of strategy the organization is trying to implement (Wright \& McMahan, 1992). The behavioral perspective links human resources management practices with successful strategy implementation (Schuler \& Jackson, 1987), thereby providing direction for achieving the critical "fit" between employee benefits practices and needed role behaviors.

As with other human resource practices, employee benefits programs and practices can be instrumental in effective strategy implementation. A recent study (Jackson, Schuler, \& Rivero, 1989) indicated that differences in personnel practices vary with organizational characteristics such as industry sector, competitive strategy, and organizational structure. Additionally, systematic differences in human resource systems have been identified and described (Arthur 1992, 1994). This research has resulted in the labeling of two very different human resource systems : control and commitment. The control human resource system is aimed at reducing direct labor costs or improving efficiency, with a focus on employee compliance with specified rules and procedures. Alternatively, the commitment human resource system attempts to forge psychological links between organizational and employee goals, while developing organizationally committed employees. In a study looking at steel minimills, Arthur (1992) found that minimills following the low-cost business strategy were more likely to have control human resource systems, while minimills following differentiation strategies were more likely to have commitment human resource systems. 
The behavioral perspective provides a basis for identifying appropriate employee benefits practices as they relate to the employee role behaviors needed for effective strategy implementation. The control and commitment human resource systems identified by Arthur $(1992,1994)$ provide additional guidance for establishing employee benefits programs that fit the organization's strategic objectives.

The major concern for organizations following a low-cost leadership strategy is on cutting costs and being efficient, while maintaining organizational quality and performance standards. Emphasis on a control human resource system would be consistent with this strategy (Arthur, 1992, 1994). Similarly, an organization pursuing a niche strategy with a low-cost focus should also find the control system to be compatible with their strategic implementation. Schuler and Jackson (1987) describe the employee role behaviors required to support a low-cost leadership strategy as consisting of repetitive and predictable behaviors, a short-term focus, autonomous activity, modest concern for quality, high concern for quantity of output, low risk-taking activities, and a relatively high degree of comfort with stability (p. 211). Successful strategy implementation requires high levels of productivity while maintaining low labor costs. Accordingly, achieving congruence with a low-cost leadership strategy requires benefits practices that emphasize control over labor costs, while maintaining employee compliance in key performance areas.

A differentiation strategy features innovation or high quality. A commitment human resource system is needed to encourage important employee role behaviors such as a high level of creative behavior, a long-term focus, and a relatively high level of cooperative behavior. High employee concern for quality is needed for organizations trying to differentiate products or services through high quality. A high degree of risk taking behavior is particularly important for organizations differentiating through innovative products and services. These critical role behaviors require flexible employees who are highly committed to the organization. The niche strategy with a differentiation approach requires comparable role behaviors consistent with a commitment human resource system.

Although control of benefits costs remains important, the shifting of costs to employees and reductions in benefits should be approached more cautiously if a differentiation strategy is followed rather than a cost control strategy. Successful implementation of a differentiation strategy requires benefits practices that are capable of forging the links between organizational and employee goals (as described by Arthur 1992, 1994). Broadly speaking, this requires maintaining a balance between cost control and providing the benefits needed to support a committed workforce with an organization-centered, future orientation. In an effort to operate with minimal overhead, while maintaining quality human resource services to employees, IBM created an outsourcing company called Workforce Solutions (Tarre, 1993). Workforce Solutions sells human resource services internally to other IBM units and is also available to provide these services externally. This change enabled IBM to save $\$ 45$ million in the first year of opera- 
tion. New efficiencies due to outsourcing included an 80 percent reduction in the number of staff required to provide benefits services supporting employees and retirees.

\section{Effective Employee Benefits Practices}

Similar to the control and commitment human resource systems, core characteristics of employee benefits practices can be conceptualized as diverse choices represented as endpoints on a series of continuum. Such a range of benefits practices is presented in Table 1, consistent with the need for diverse types of human resource systems to support a low cost or differentiation strategy. The representation of these two "ideal" forms is not intended to preclude the possibility of an organization that successfully combines aspects of both.

\section{Table 1}

\section{Employee Benefits Practices Displayed by Strategic Choice and Core Characteristic}

\begin{tabular}{|c|c|c|}
\hline \multirow[b]{2}{*}{ Core Characteristic } & \multicolumn{2}{|c|}{ STRATEGIC CHOICE } \\
\hline & Low-Cost & Differentiation \\
\hline Timing & $\begin{array}{l}\text { Low percentage of deferred } \\
\text { compensation } \\
\text { Minimal benefits } \\
\text { Relatively stable over time }\end{array}$ & $\begin{array}{l}\text { High percentage of } \\
\text { deferred compensation } \\
\text { Progressive benefits } \\
\text { Adapts with worker age }\end{array}$ \\
\hline Benefits Costs & $\begin{array}{l}\text { Meets or follows competition } \\
\text { Low percentage of labor } \\
\text { cost } \\
\text { Emphasis on basic } \\
\text { needs }\end{array}$ & $\begin{array}{l}\text { Leads competition } \\
\text { High percentage of } \\
\text { labor cost } \\
\text { Emphasis on flexibility } \\
\text { or comprehensiveness }\end{array}$ \\
\hline $\begin{array}{l}\text { Employee-Employer } \\
\text { Relationship }\end{array}$ & $\begin{array}{l}\text { Low percentage of full-time } \\
\text { benefitted workers } \\
\text { Low participation in } \\
\text { decision-making } \\
\text { Cost orientation } \\
\text { Simple one-way } \\
\text { communications }\end{array}$ & $\begin{array}{l}\text { High percentage of full. } \\
\text { time benefitted workers } \\
\text { High participation in } \\
\text { decision-making } \\
\text { Need orientation } \\
\text { Complex interactive } \\
\text { communication }\end{array}$ \\
\hline
\end{tabular}


A number of core characteristics seem to exemplify the systematic differences needed to support a diverse set of employee role behaviors. While the following characteristics of employee benefits practices should not be considered exhaustive, it is representative of the key issues for strategic implementation. Each of three core characteristics will be described in the following sections with examples of possible benefits practices that can be used to encourage the needed employee attitudes and behaviors.

\section{Timing}

One of the critical differences between the low cost and differentiation strategies is the future orientation. A short-term focus is generally characteristic of a low-cost strategy. Alternatively, differentiation through quality-enhancement requires an intermediate to long-term focus (Schuler \& Jackson, 1987). Accordingly, these variations in future orientation should be reflected in employee benefit practices that emphasize the delivery of rewards to employees at the appropriate time. A short-term perspective requires that the timing of rewards emphasize the present. Rewards that are timed to be experienced in the future, rather than the present, support a longer-term focus. In general, "companies that want people to stay for a long time need benefits that bind the individual to the corporation" (Greller \& Nee, 1989, p. 191).

Deferred compensation provides a good example of a practice that can be timed to support an organization's choice of strategy. A high percentage of deferred compensation favors the employee longevity needed for a longer-term focus. Pension plans are an important form of deferred compensation. Vesting requirements and related practices can penalize the employee for leaving the organization before retirement age. These practices increase the cost of leaving the organization, thereby, serving to bind employees to the organization for longer periods of time.

This has been the choice of Dow Chemical Company, which has maintained a retirement benefit based on years of service, to encourage a stable workforce. Alternatively, Wendy's International restructured retirement benefits to improve portability for employees, while supporting the company needs for flexible staffing and quality managers (Murray, 1993). Research supports the view that deferred compensation practices can act as deterrents to leaving the organization (Mitchell, 1982, 1983). Additional evidence indicates that the extraordinarily low quit rates associated with federal employees is due to the large portion of pay given as pensions and the large reductions in pension pay-outs incurred by workers who leave before retirement (Ippolito, 1987).

Also consistent with a longer-term focus is the use of progressive benefits. Progressive benefits, which increase in value as employee tenure increases, can be used to retain employees (Gomez-Mejia \& Balkin, 1992). Retirement benefits would be included in this category as would forms of paid time-off. Since benefits such as vacation time and sick leave increase with length of employee tenure, so do the costs associated with leaving the organization. These efforts at 
workforce retention are more critical to the longer-term focus of the differentiation strategy.

Another issue of timing can be reflected in the types of benefits included in the benefits package. As people age, the benefits they are most interested in change. For example, the issues involving retirement and medical benefits are likely to increase in importance as the workforce ages (Greller \& Nee, 1989). Some large employers such as General Motors Corporation and American Express Company have been attempting to meet the needs of their aging workforce by adding long term care insurance to benefits packages (Sears, 1992). Providing long term care insurance, generally entirely paid by employees, enables participants to better plan for future needs during retirement years. By providing long term care insurance the employer shows concern for employee retirement concerns, while emphasizing employee responsibility for personal planning.

For organizations that are emphasizing retention and longer tenure, the availability of the right benefits at the right time is a critical concern. Binding workers to the organization, therefore, requires benefits that can adapt to the changing needs of an aging workforce. Where cost control is more critical than adaptability, providing a minimal benefits package maintained over time can better serve a fluctuating, short-tenured workforce. Basic benefits such as health insurance emphasize the current needs of a wide range of workers, rather than the needs of more specific demographic groups.

\section{Benefits' costs}

When determining the appropriate costs of benefits, both the overall compensation and the percentage of benefits relative to pay are key considerations. The compensation policy determines the total number of dollars available for pay and benefits. The traditional policy choices regarding compensation level are to lead, meet, or follow the competition (Milkovich \& Newman, 1993). The decision to lead, meet, or follow the competition is an important factor for stimulating the inflow and outflow of human resources (Gomez-Mejia \& Balkin, 1992). An organization adopting a lead policy provides compensation at a level above that provided by organizations competing for the same workers. Accordingly, "a lead policy maximizes the ability to attract and retain quality employees" (Milkovich \& Newman, 1993, p. 213). A lead policy is more consistent with a differentiation strategy which requires a workforce committed to organizational goals. The longer-term focus of a differentiation strategy, as well as the development of employee commitment and flexibility, require longer-term worker retention and employment stability.

Alternatively, an organization can adopt a meet or follow policy. An organization pursuing a meet policy attempts to set the compensation rate at a level similar to its market competitors. A policy that meets or matches the competition prevents the organization from being placed at a competitive disadvantage, making this a popular choice (Gomez-Mejia \& Balkin, 1992). An organization 
choosing to pay at a rate lower than its competition typifies the follow the market decision to achieve broader compensation objectives.

The lead, meet, or follow policy influences the total number of dollars available for compensation, and therefore, affects benefit costs. Since employee benefits are only a portion of compensation costs, the proportion of labor costs dedicated to the benefits portion of the compensation package is an important issue. Choices regarding the mix of various forms of compensation (e.g., pay and benefits) can directly affect management's ability to meet strategic performance goals (Milkovich \& Broderick, 1991). Dreher, Ash, and Bretz (1988) found a negative relationship between pay and benefits levels, in a study of the uniformed members of seven law enforcement agencies. This finding suggests that a high pay level may not be matched with high benefits, but instead is more likely to be offset by lower benefits levels. Factors such as tax advantages and group discounts encourage employees to trade-off pay in return for more benefits, as can be represented by a compensatory model (Gerhart \& Milkovich, 1992). However, it should be noted that as benefits costs have risen for even basic benefits such as health insurance, many organizations have found effective ways to control these benefits costs, and accordingly labor costs. This implies that effective strategic planning for employee benefits involves a two-step process. First, a decision determining total compensation is made. Then, the portion of compensation devoted to benefits is established.

Dramatic changes have occurred in the labor force over the past two decades. Trends such as the increasing participation of women, dual-earner families, and a shift from manufacturing to service industries, have resulted in significant shifts in the benefits workers need (Meisenheimer \& Wiatrowski, 1989). During this same period, factors including pressures from unions and tax advantages have stimulated expansion of the benefits portion of compensation (Milkovich \& Newman, 1993) as reflected in higher benefits levels and the introduction of many new benefits.

For organizations pursuing a low-cost strategy, offering basic benefits such as life and health insurance in place of pay, can be cost effective due to the associated tax advantages. Limiting the employee benefits plan so that it emphasizes only the basic needs common to virtually all workers can provide cost effective compensation. Providing too large a benefits plan, however, might unnecessarily bind workers to the organization because of their inability to secure comparable arrangements elsewhere.

In support of a low-cost strategy, the organization should maintain low labor costs. Walker Manufacturing, a supplier of mufflers to the automotive industry, provides an illustration of a compensation program supporting a low-cost strategy. In order to lower overall labor costs, at Walker Manufacturing, employees do not become permanent, benefitted workers until they complete one year of service. Additionally, permanent employees are required to make a small monetary contribution for health insurance coverage. Although, attracting workers requires a meet the competition policy for wage and benefit levels, the heavy 
reliance on non-benefitted temporary workers is intended to keep down overall labor costs. Controlling the number of employees eligible for benefits through the use of part-time and temporary workers is a practical method for reducing overall benefit costs, particularly when competitive pressures or union agreements prevent limiting or reducing benefits packages.

In other cases, a low-cost strategy can require more extensive efforts to contain labor costs. In order to meet the demand for boxed beef products at low costs, Litvak Packing Company evolved into the Champion Boxed Beef Company. A comparison of union-management contracts from Litvak Packing Company in the 1970s and Champion Boxed Beef Company in the 1990s provides an illustration of efforts to contain compensation and achieve a low-cost strategy, as both wages and benefits for workers declined over an extended period of time. According to the 1976 contract, full-time employees were entitled to a week of paid vacation after one year with an additional week added after three, eight, fifteen and twenty-five years of service. In 1994, employees were entitled to a week after one year and an added week after three and ten years of service, with no mention of the supplemental weeks for longer service as was contained in the 1970s contract. Similarly, pension plans changed over time. Current employees are eligible for profit sharing with payouts based on company financial performance. These payout funds, although not guaranteed, can be used for retirement purposes. However, Litvak Packing Company employees received an employerpaid pension upon retirement.

A higher reliance on benefits, particularly those that help to attract and retain a stable workforce, can result in a higher percentage of labor cost being reflected in the benefits portion of compensation, thereby supporting implementation of a differentiation strategy. The proliferation of benefits can assist employers in binding workers to the organization not only financially, but also emotionally. Milkovich and Newman (1993) conclude, "many employer-initiated benefits were designed to create a climate in which employees perceived that management was genuinely concerned for their welfare" (p. 398). Increasing the comprehensiveness of the benefits package, therefore, is consistent with the requirements of a differentiation strategy. In order to support quality products and quality of life for employees, Stride Rite Corporation introduced a number of family friendly benefits that enable workers to better balance work and family concerns. Stride Rite's commitment to employees is reflected in benefits such as extensive childand elder-care assistance, educational scholarships to dependents of workers, and a paid family leave policy (Laabs, 1993).

The use of flexible benefits plans has increased as an alternative to large comprehensive plans (Meisenheimer \& Wiatrowski, 1989). Reasons for adopting a flexible benefits approach typically include the ability to contain costs while at the same time covering a wide range of employee needs (McCaffery, 1988). Flexible benefits or cafeteria plans allow employees to allocate benefits dollars to the benefits that best meet their personal needs, enabling them to experience the greatest possible value for their compensation dollars. While the use of flexible ben- 
efits is not solely beneficial for organizations with many types of benefits, the increased cost of administering a flexible plan is a key consideration in strategic implementation. More important than this issue of benefits program administration is the specific types of benefits included by the employer.

\section{Employee-employer relationship}

As global competition has increased, many organizations have tried to cut overhead costs by downsizing. This is just one indication that important changes are occurring in the employee-employer relationship. From the individual's perspective, organizational life will never be the same, with the likely outcomes being shorter organizational tenure, as well as decreased loyalty and commitment. While virtually all organizations have been affected by skyrocketing costs of health care and other benefits, the manner in which the organization controls these costs can also send a strong message to employees. For example, the Adolph Coors Company opened a wellness center for employees with projected savings based on the avoidance of future health care costs (Bunch, 1992). Alternatively, the retail grocery industry has come under recent attack by union groups for their practice of utilizing part-time unbenefitted workers to hold down labor costs. These dramatically different types of response to the need to hold down benefits costs have major implications for the employee-employer relationship.

The reduction in full-time positions generally decreases the benefits portion of the compensation budget, by reducing the number of workers included in the organization's benefits program. Approximately 25 percent of the U.S. civilian work force is composed of what are termed "contingent workers" (Mathis \& Jackson, 1994 , p. 38 ), who regularly work only part-time or on a temporary basis Since contingent workers are not part of the organization's full-time work force, they frequently do not receive benefits, thereby lowering overall labor costs. In an organization that does not need a long-term committed work force, such as when a low-cost strategy is employed, the replacement of full-time workers with contingent workers and outside consultants can be an effective way to reduce the benefits portion of labor costs. Prudent use of part-time workers can increase staffing flexibility, while reducing labor costs. However, it should be remembered that frequently full-time positions cut during lay-offs are later replaced by more expensive consultants. The replacement of full-time, benefitted workers by consultants can often result in an overall increase, rather than decrease in actual costs (Cascio, 1993). As with any human resource practice a careful cost/benefit analysis is required to determine congruity with organizational objectives.

Allowing employees to participate in decision-making can assure that compensation dollars are spent in ways that maximize benefits for workers. This approach is supported by research which has identified an increase in satisfaction occurring after a change from a standard benefits package to a flexible benefits package (Barber, Dunham, \& Formisano, 1992). Lawler (1991) suggests that an organization adopting a high employee involvement approach can allow employ- 
ees a great deal of flexibility in the decisions regarding their own rewards package. Allowing employee participation, as in the case of flexible benefits, conveys the important message that the employer values employees and has confidence in their ability to make decisions (Lawler 1990). A high participation approach is consistent with the type of employee-employer relationship needed to support a differentiation strategy. Although the current trend is toward more flexibility in compensation and benefits programs (McCaffery, 1988), the costs of flexibility can increase communication and administrative costs. These increased costs are likely to continue to act as a deterrent to increasing employee participation in organizations choosing a low-cost strategy.

As new types of benefits have been added to employer-sponsored packages, a resulting side effect has been the increased employer involvement in the nonwork lives of employees. As employees become more reliant on employers in nonwork areas such as childcare assistance "the bond between employee and employer can be profoundly affected" (Guzzo, Nelson, \& Noonan, 1992, p. 245). The historical evolution of benefits has not only increased employer involvement in employees' nonwork lives, but has encouraged the expectation that the employer will take care of employee needs. As argued by Lucero and Allen (1994), this gradual change in the employee-employer relationship, has resulted in an adversarial relationship between employees and employers with respect to benefits. While employers are increasingly concerned with benefit costs, employees are increasingly concerned about their ability to meet their own financial and security needs. Employers who wish to maintain a stable, long-term work force should consider ways to continue to cover employee needs, thereby preventing the disruption of the important employee-employer relationship. Manor HealthCare Corporation found the emphasis on employee needs to be an important value for their high service industry. The benefits package was designed to reward length of service while improving health insurance and pension contributions for lower paid employees (Gunsch, 1993).

Where cost and efficiency are the primary values, communication with employees should emphasize the cost of benefits as a portion of employee total compensation. This emphasis on dollar value can deliver the message that the employer's responsibility is to fairly compensate, rather than provide for many personal needs. Not only is the content of communication defined by the strategic objectives, but the form of communication is also variable. The content of communication is important, since it provides information about how the employer views the nature of the employee-employer relationship. Additionally, past research (Wilson, Northcraft, \& Neale, 1985), indicates that many employees are unaware of some of the benefits provided, as well as the financial value. This suggests the need for employers to adequately inform employees of the cost and coverage of the benefits package. The form of communication, therefore, must also be adapted to employee requirements for information. Where the employee benefits package contains only basic coverage, one-way communications are probably appropriate. However, complex, interactive communication forms are a cru- 
cial aspect of an effective program when the employee benefits provided are more comprehensive.

\section{Conclusions}

Factors such as escalating employee benefit costs and increasing global competitive pressures indicate the need to manage employee benefit practices more efficiently. The core characteristics of employee benefits can be matched to the organization's choice of strategy. This linking of employee benefit practices to strategy can provide significant ways to improve organizational effectiveness and efficiency.

Control and commitment human resource systems can be viewed as opposite ends of a continuum of human resource systems (Arthur, 1994), providing a useful typology by which to examine the range of possible employee benefits practices. This, of course, suggests that many organizations will contain a mix of control and commitment characteristics, thereby including a combination of employee benefits practices, rather than the ideal types described in this paper. Similarly the core characteristics of employee benefits can be conceptualized as a continuum with opposite ends in the control versus commitment human resource systems.

Creating "fit" between the core characteristics and the choice of strategy can help secure employee behaviors and attitudes necessary for successful strategy implementation. This strategic approach can provide direction in the planning and management of human resources, thereby promoting organizational effectiveness and efficiency with respect to labor costs.

For researchers, this approach provides the basis for examining an important issue that has been generally neglected. The strategic approach outlined in this paper describes the relationships between the organization's choice of strategy and employee benefits practices, as well as associated employee role behaviors needed for effective strategy implementation. Future empirical research is needed to examine the impact that such a "fit" can have on organizational performance.

Linking benefits to strategy also has important practical implications for managers. The proposed framework provides a method for examining the contribution that benefits can make towards eliciting and reinforcing the workplace attitudes and behaviors required for effective strategy implementation. Awareness of these linkages is especially important as managers engage in efforts to control the costs of benefits. Two underlying assumptions of this view should be highlighted. First, today's competitive environment requires that employee benefits practices be examined as an integral part of human resource and corporate strategic planning. Effective and efficient organizations should focus on accomplishing congruence across all organizational functions. Second, all cost containment techniques are not created equal. The control and commitment systems highlighted in this paper provide some of the linkages between the needed employee out- 
comes and the organization's strategic choice. Thinking about employee benefits practices strategically can enable organizations to realize cost savings while enhancing the appropriate employee attitudes and behaviors.

\section{References}

Arthur, J. B. "Effects of human resource systems on manufacturing performance and turnover." Academy of Management Journal 37 (June 1994): 670-687.

Arthur, J. B. "The link between business strategy and industrial relations systems in American steel minimills." Industrial and Labor Relations Review 45 (April 1992): 488506.

Barber, A. E., Dunham, R. B., and Formisano, R. A. "The impact of flexible benefits on employee benefit satisfaction: A field study." Personnel Psychology 45 (Spring 1992): $55-75$.

Barney, J. "Firm resources and sustained competitive advantage." Journal of Management 17 (March 1991): 99-120.

Boulding, K. The Image. Ann Arbor, MI: University of Michigan Press, 1956.

Bunch, D. K. "Coors Wellness Center-helping the bottom line." Employee Benefits Journal 17 (March 1992): 14-18.

Carswell, B. "How rightsizing affects benefits." In P. Lacey (Ed.), New Strategies for Employee Benefits. 11-12. New York: The Conference Board, 1986.

Cascio, W. F. "Downsizing: What do we know? What have we learned?" Academy of Management Executive 7 (Feb. 1993): 95-104.

Dreher, G. F., Ash, R. A., and Bretz, R. D. "Benefit coverage and employee cost: Critical factors in explaining compensation satisfaction." Personnel Psychology 41 (1988): 237254.

Gerhart, B. and Milkovich, G. "Employee compensation: Research and practice." In M. D. Dunnette \& L. M. Hugh (Eds.), Handbook of industrial and organizational psychology. 2nd Edition, 481-569, Palo Alto, CA: Consulting Psychologists Press, Inc., 1992.

Gomez-Mejia, L. R. and Balkin, D. B. Compensation, Organizational Strategy, and Firm Performance. Cincinnati, OH: South-Western Pub. Co. 1992.

Greller, M. M. and Nee, D. M. From Baby Boom to Baby Bust: How Business Can Meet the Demographic Challenge. Reading, MA: Addison-Wesley Pub. Co. 1989.

Gunsch, D. "Benefits program helps retain frontline workers." Personnel Journal 72 (February 1993): 88-94. 
Guzzo, R., Nelson, G., and Noonan, K. "Commitment and employer involvement in employees' nonwork lives." In S. Zedeck (Ed.), Work, families and organizations, San Francisco: Jossey-Bass, 1992.

Ippolito, R. A. "Why federal workers don't quit." Journal of Human Resources 22 no. 2 (1987): 281-299.

Jackson, S. E., Schuler, R. S., and Rivero, J. C. "Organizational characteristics as predictors of personnel practices." Personnel Psychology 42 (Winter 1989): 727-786.

Jones, G. "Task visibility, free riding, and shirking: Explaining the effect of structure and technology on employee behaviors." Academy of Management Review 9 (October 1984): 684-695.

Laabs, J. J. "Family issues are a priority at Stride Rite." Personnel Journal 72 (July 1993):48-56.

Lawler, E. E. Strategic Pay. San Francisco: Jossey-Bass, 1990.

Lawler, E. E. "Employee involvement and pay system design." In M. L. Rock \& L. A. Berger, The Compensation Handbook: A State-of-the-Art Guide to Compensation Strategy and Design. 3rd Edition, 592-603. New York: McGraw-Hill Inc., 1991.

Lucero, M. A. and Allen, R. E. "Employee benefits: A growing source of psychological contract violations." Human Resource Management Journal 33 (Fall 1994): 425-446.

Mathis, R. L. and Jackson, J. H. Human Resource Management. Minneapolis, St. Paul: West Publ. Corp., 1994.

McCaffery, R. M. Employee Benefit Programs: A Total Compensation Perspective. Boston: PWS-Kent Publishing Co., 1998.

Meisenheimer, J. R. and Wiatrowski, W. J., "Flexible benefits plans: employees who have a choice." Monthly labor Review 112 (December 1989): 158-164.

Milkovich, G. T. and Broderick, R. F. "Developing a compensation strategy." In M. L. Rock \& L. A. Berger, The Compensation Handbook: A State-of-the-Art Guide to Compensation Strategy and Design. 3rd Edition, 24-29. New York: McGraw-Hill, Inc., 1991.

Milkovich, G. T. and Newman, J. M. Compensation., 4th Edition, Homewood, IL: Irwin, 1993.

Mitchell, O. S. "Fringe benefits and labor mobility." Journal of Human Resources 17 (1982): $286-298$.

Mitchell, O. S. "Fringe benefits and the cost of changing jobs." Industrial and Labor Relations Review 37 (1983): 70-78. 
Murray, K. A. "How HR is making pensions portable." Personnel Journal 72 (July 1993): 36-45.

Porter, M. E. Competitive strategy: Techniques for analyzing industries and competitors. New York: Free Press 1980.

Porter, M. E. Competitive advantage. New York: Free Press, 1985.

Sager, I., McWilliams, G. and Hof, R. D. "IBM leans on its sales force." Business Week (February 7, 1994): 110.

Schuler, R. S. and Jackson, S. E. "Linking competitive strategies with human resource management practices." Academy of Management Executive 1 (August 1987): 207-219.

Sears, R. W. "Why offer long term insurance?" In T. Brothers (Ed.), Controlling the Costs of Employee Benefits, 30, New York: The Conference Board, 1992.

Tarre, M. "WFS Workforce Solutions: Outsourcing the benefit function." In P. Lacey (Ed.), New Strategies for Employee Benefits, 11-12, New York: The Conference Board, 1993.

Thompson, A. A. Jr. and Strickland, A. J. III. Strategic Management. Homewood: Irwin, 1992.

U. S. Chamber of Commerce Employee Benefits. 1992 Edition, Washington, DC.,1992.

Wilson, M., Northcraft, G, B., and Neale, M. A. "The perceived value of fringe benefits." Personnel Psychology, 38 (1985): 309-320.

Wright, P. M. and McMahan, G. C. . "Theoretical perspectives for strategic human resource management." Journal of Management, 18 (June 1992): 295-320. 